\title{
GAMBARAN PENGETAHUAN ORANG TUA TENTANG IMUNISASI MEASLES RUBELLA DI MADRASAH IFTIDAIYAH AL-KAUTSAR PALEMBANG TAHUN 2019
}

\author{
Oleh ; \\ Khoirin ${ }^{1}$, Mirsa Hardianti ${ }^{2}$ \\ 1,2 Program Studi DIII Keperawatan, STIKES ‘Aisyiyah Palembang \\ Khoirinmugiman@gmail.com \\ mirsa.hardianti@,Gmail.com
}

\begin{abstract}
ABSTRAK
Latar Belakang : Menurut World Health Organization (WHO), program Imunisasi di indonesia memiliki tujuan untuk menurunkan angka kejadian penyakit dan angka kematian akibat penyakit yang dapat dicegah dengan imunisasi. upaya imunisasi diselenggarakan di indonesia sejak tahun 1956. mulai tahun 1977, upaya imunisasi diperluas menjadi program pengembangan imunisasi dalam rangka pencegahan penularan terhadap Penyakit yang Dapat Dicegah Dengan Imunisasi (PD3I) seperti penyakit Tuberculosis, Difteri, Pertusis, Campak, Tetanus, Polio, Hepatitis , Pneumonia, Rotavirus, Sindrome Rubella Kongenital, Human Papiloma Virus. Tujuan penelitian ini untuk mengetahui gambaran pengetahuan orang tua tentang Imunisasi Measles Rubella di Madrasah Ibtidaiyah Al-Kautsar Palembang pada tahun 2018. Metode penelitian ini menggunakan desain penelitian Deskriftif Kuantitatif,sampel di ambil dengan menggunakan accidental sampling yang berjumlah 34 orang tua di madrasah iftidaiyah al-kautsar yang berada di wilayah kerja Puskesmas Nagaswidak. Analisis data menggunakan Analisa Univariat, penelitian ini di lakukan di bulan januari 2019. Hasil Penelitian sebagian besar dari 34 responden diketahui ada $20(58,8 \%)$ responden mempunyai pengetahuan yang baik tentang imunisasi, sedangkan $11(32,4 \%)$ responden mempunyai pengetahuan yang cukup dan 3(8,8\%) yang mempunyai pengetahuan kurang. Saran : Diharapkan untuk penelitian yang akan datang dapat menggunakan variabel yang lebih bervariasi dan mencakup penelitian yang lebih luas, sehingga penelitian tentang imunisasi measles dan rubella dapat terus berkembang.
\end{abstract}

Kata Kunci : : Imunisasi Measles Rubella, Pengetahuan

\begin{abstract}
Background:according to the world health organization (WHO) Indonesia' Immunization program has a goal of reducing Immune-preventable disease and mortality rates. Immunization efforts have been held in Indonesi since 1956. Beginning in 1977, Immunization efforts were expanded into an immunization development program in the prevention of immunization of disease infections (pd3i) such as immunodeficiency, diphtheria, pertusis, measles, tetanus, polio, hepatitis, pneumonia, rotavirus, congenital rubella syndrome, human papillomas. The goal of this studyis to find out what parent's awareness of the immunization of emergency Bella in the madrassa ibtidayah al-kautsar palembang in 2018. This method of research uses the quantitative descriptive research design, the sample was taken using the 34-parent sampling of madrasah iftidaiyah al-kautsar who is nagaswidak area of labor center. Data analysis using a Univariate analysis, the study was performed in January 2019. The vast majority of 34 respondents were known to have $20(58,8 \%)$ when $11(32,4 \%)$ had a good knowledge of immunization, while $11(32,4 \%)$ had sufficient knowledge and $3(8,8 \%)$ had little knowledge. Suggestions: it is hoped that studies could use more varied variables and cover more broader research, so tah research on disease disease and disease could be constantly improved.
\end{abstract}

Keyword : Immunization rubella measles, knowledge 


\section{PENDAHULUAN}

Imunisasi berasal dari kata imun yang berarti kebal atau resisten anak diimunisasikan berarti memberi kekebalan terhadap suatu penyakit tertentu (Marimbi, 2010). Imunisasi adalah cara untuk meningkatkan kekebalan seseorang terhadap suatu penyakit, sehingga bila kelak terpajan penyakit tersebut ia tidak menjadi sakit. Kekebalan yang di peroleh dari imunisasi dapat berupa kekebalan pasif maupun aktif (Viantri ,2018)

Pemberian Imunisasi Tambahan di berikan pada kelompok umur tertentu yang paling beresiko terkena penyakit sesuai dengan kajian epidemiologis pada periode waktu tertentu, yang termasuk dalam Imunisasi Tambahan adalah backlog fighting, crash program,PIN (Pekan Imunisasi Nasional ), Sub-PIN. Catch up campaign Campak Dan Imunisasi dalam penanganan KLB (Outbreak Response Immunization / ORI ). (Viantri, 2018).

\section{Menurut World Health Organization} (WHO), program Imunisasi di indonesia memiliki tujuan untuk menurunkan angka kejadian penyakit dan angka kematian akibat penyakit yang dapat dicegah dengan imunisasi. Upaya imunisasi diselenggarakan di Indonesia sejak tahun 1956. Mulai tahun 1977, upaya Imunisasi diperluas menjadi program pengembangan
Imunisasi dalam rangka pencegahan penularan terhadap Penyakit yang Dapat Dicegah Dengan Imunisasi (PD3I) seperti penyakit Tuberculosis, Difteri, Pertusis, Campak, Tetanus, Polio, Hepatitis , Pneumonia, Rotavirus, Sindrome Rubella Kongenital, Human Papiloma Virus. (MKPP ‘Aisyiyah, 2018 ).

Indonesia di perkirakan mengalami kerugian ekonomi akibat penyakit Measles-Rubella (MR) mencapai Rp 5,7 Triliun. Indonesia merupakan satu dari 10 negara dengan jumlah kasus Campak terbesar di Dunia pada tahun 2015 menurut Badan Kesehatan Dunia (WHO). Kemenkes mencatat jumlah kasus Campak dan Rubella dalam 2014 sampai dengan juli 2018 mencapai 57.056 kasus (8.964 positif campak dan 5.737 positif Rubella ).

Pada tahun 2014, terdapat 12,943 kasus suspek Campak Rubella (2.241 positif campak dan 906 positif rubella. Pada tahun 2015, tercatat 13.890 kasus suspek Campak Rubella dengan 1.194 jiwa positif Campak dan 1.474 positif Rubella. Pada tahun 2016, angka sedikit menurun dengan hanya tercatat 12.730 kasus suspek campak rubella yang tercatat dengan 2.949 positif campak dan 1.341 positif rubella. Namun di tahun 2017, kasus ini tercatat kembali naik menjadi 15.104 kasus. 383 kasus positif campak dan 732 positif rubella. 
Selama 4 tahun terakhir hingga Juli 2018, data rumah sakit di seluruh Indonesia mencatat 1.660 kasus CRS (Congenital rubella syndrome) telah terjadi. Biaya minimal yang di butuhkan untuk anak penderita CRS mencapai $\mathrm{Rp}$ 395 juta per orang dana itu sudah termasuk untuk penanganan koklea dan telinga, operasi jantung dan mata. Biaya itu belum termasuk biaya perawatan kecacatan seumur hidup. (Novelino, 2018).

Indonesia merupakan Negara yang mewajibkan Imunisasi dan ada juga yang hanya dianjurkan, Imunisasi wajib di Indonesia sebagaimana telah ditetapkan oleh WHO ditambah dengan Hepatitis $B$. Imunisasi yang dianjurkan oleh pemerintah dapat digunakan untuk mencegah suatu kejadian yang luar biasa atau penyakit endemik, atau untuk kepentingan tertentu (berpergian) seperti jamaah haji seperti imuniasasi meningitis (Novelino, 2018).

Rubella adalah penyakit yang akut dan ringan yang sering menginfeksi anak dewasa muda yang rentan. Di Indonesia, merupakan salah satu malsalah kesehatan yang memerlukan upaya pencegahan efektif. Data surveilans selama lima tahun terakhir menunjukkan 70\% kasus rubella terjadi ada kelomok usia $<15$ tahun. Selain itu, berdasarakan studi tentang estimasi beban penyakit CRS di Indonesia pada tahun 2013 diperkirakan terdapat 2767 kasus CRS, 82/100.000 terjadi pada ibu usia 15-19 tahun dan menurun menjadi 47/100.000 pada usia ibu 40-44 tahun. (KKRI, 2017).

Imunisasi MR di Sumsel belum mencapai target. Hanya mampu mencapai target sekitar $78 \%$ dari target 2.239.000 anak. Capaian tersebut dinilai belum memuaskan, di karenakan target nasional mencapai 95\%. Berdasarkan data yang di himpun Dinkes Sumsel, daerah Sumsel yang capainya masih rendah yakni salah satunya Kota Palembang masih rendah yakni 56\%, karena memang targetnya cukup banyak di bandingkan Kabupaten / Kota di Sumsel dari target sekitar 400 ribu anak. (Sriwijaya Post,2018).

Kecilnya cakupan Imunisasi dikarenakan kurangnya Pengetahuan orang tua tentang MR dan fenomena yang ada di masyarakat mengenai kecacatan setelah di lakukan Imunisasi MR . Berdasarkan study pendahuluan di Madrasah Iftidaiyah AlKautsar bahwa dari 5 orang tua yang di temui saat study pendahuluan ada 4 orang tua yang belum mengetahui tentang imunisasi Measles Rubella dan 1 orang tua masih ragu akan kehalalan vaksin yang akan di berikan, walaupun sebelum melakukan Imunisasi Pihak Sekolah memberikan lembar persetujuan pada orang tua agar anaknya di Imunisasi.

Dari uraian data di atas terlihat masih kecilnya cakupan imunisasi yang menjadi 
target pemerintah yang di sebabkan salah satunya adalah karena kurangnya pengetahuan masyarakat terhadap pentingnya Imunisasi bagi anak dan dalam upaya pencegahan (Preventif) terhadap berbagai penyakit salah satunya adalah penyakit Rubella. Sehingga sangat di perlukan suatu upaya Promotif terhadap masyarakat tentang pentingnya vaksinasi bagi bayi, anak dan remaja, dalam upaya tersebut maka penulis merasa perlu untuk menggambarkan suatu penelitian tentang pengetahuan orang tua tentang Imunisasi Measles Rubella di Madrasah Ibtidaiyah Al-Kautsar palembang.

\section{METODELOGI PENELITIAN}

\section{A. Desain Penelitian}

Metode penelitian yang digunakan dalam penelitian ini adalah penelitian dengan cara deskriptif - kuantitatif yaitu suatu metode penelitian yang dilakukan dengan tujuan untuk mengetahui Gambaran Pengetahuan Orang Tua Tentang Pengetahuan Imunisasi Measles Rubella di Madrasah Ibtidaiyah Al-Kautsar Palembang Tahun 2018 (Notoatmodjo, 2012).

\section{Populasi}

Populasi adalah seluruh individu yang akan dikenai sasaran generalisasi dari sampel yang akan diambil dalam suatu penelitian (Hadi, 2004 dalam Sumantri, 2011). Populasi dalam penelitian ini adalah orang tua siswa kelas 1 dan 2 di
Madrasah Ibtidaiyah Al-Kautsar Palembang tahun 2019.

2. Sampel

Sampel adalah sebagian yang diambil dari keseluruhan objek yang diteliti dan dianggap mewakili seluruh populasi (Notoatmodjo, 2010). Sample dalam penelitian ini adalah Orang Tua Siswa kelas 1 dan 2 di Madrasah Ibtidaiyah Al-Kautsar Palembang tahun 2019 sebanyak 34 sample. Cara mengambil sample dalam penelitian ini adalah dengan menggunakan Accidental Sampling (sampel yang ada pada saat penelitian atau responden yang ada pada saat melakukan penelitian). Adapun Kriteria Inklusi sebagai berikut:

1. Orang Tua siswa kelas 1 dan 2 di Madrasah Ibtidaiyah AlKautsar

2. Orang Tua yang bersedia menjadi responden.

\section{Orang Tua yang dapat} membaca dan menulis.

4. Orang Tua yang bisa mendengar dengan baik.

3. Tempat Penelitian

Lokasi penelitian di lakukan di Madrasah Ibtidaiyah Al-Kautsar Palembang Tahun 2019. 
4. Waktu Penelitian

Penelitian ini di lakukan pada bulan Januari tahun 2019

5. Teknik Penggumpulan Data

Pengumpulan data untuk penelitian ini menggunakan data primer yaitu dengan menggunakan alat ukur berupa kuisioner yang di susun oleh penulis berdasarkan teoritisnya. Penulis memberikan penjelasan singkat terlebih dahulu kepada responden tentang tujuan penelitian. Untuk mengisi kuesioner, penelitian mendatangi Orang Tua Siswa Madrasah Ibtidaiyah Al-Kautsar Palembang tahun 2019 menjadi sample.

\section{Pengolahan Data}

Kegiatan atau langkah-langkah yang dilakukan peneliti dalam pengolahan data (Notoatmodjo, 2012) yaitu :

1. Editing (memeriksa)

Editing adalah merupakan kegiatan pengecekan dan perbaikan isian formulir atau kuesioner tersebut, meliputi: kelengkapan jawaban, keterbacaan tulisan, relevansi jawaban, dan konsitensi jawaban pertanyaan dengan jawaban.

2. Coding (pengkodean)

Coding adalah mengklasifikasikan jawaban-jawaban dari para responden kedalam kategori, yakni mengubah data berbentuk kalimat atau huruf menjadi data angka atau bilangan.
3. Entry (memasukan data)

Entry adalah jawaban-jawaban dari masing-masing responden yang dalam bentuk Skode (angka atau bilangan) dimasukkan ke dalam program komputer.

4. Cleaning (pembersihan data)

Apabila semua data dari setiap sumber data atau responden selesai dimasukkan, perlu dicek kembali untuk melihat kemungkinankemungkinan adanya kesalahankesalahan kode, ketidak lengkapan, dan sebagainya, kemudian dilakukan pembetulan atau koreks.

\section{Analisis Data}

Data akan diolah dan akan dianalisis dengan teknik-teknik tertentu, yaitu dengan menggunakan teknik analisis kuantitatif, melalui proses komputerisasi dengan Analisis Univariat. Analisa univariat adalah suatu variabel yang menggambarkan penyajian data satu variabel saja (Notoatmodjo, 2010). Analisis univariat dilakukan untuk melihat distribusi frekuensi pengetahuan Orang Tua tentang ilmunisasi Measles

Rubella.

\section{Analisa Univariat}


Analisa univariat adalah suatu

variabel yang menggambarkan

penyajian data satu variabel

saja (Notoatmodjo, 2010).

Analisis univariat dilakukan

untuk melihat distribusi

frekuensi pengetahuan Orang

Tua tentang ilmunisasi Measles

Rubella.

HASIL DAN PEMBAHASAN Analisa

Univariat
Analisa univariat adalah suatu variabel yang menggambarkan penyajian data satu variabel saja (Notoatmodjo, 2010). Analisis univariat dilakukan untuk melihat distribusi frekuensi pengetahuan Orang Tua tentang ilmunisasi Measles Rubella.

\section{Pengertian Imunisasi}

Berdasarkan hasil penelitian terhadap 34 responden tentang Pengertian Imunisasi di Madrasah Ibtidaiyah AlKautsar Palembang tahun 2019 di dapatkan data sebagai berikut.

\section{Tabel 1}

Distribusi Frekuensi Responden berdasarkan pengetahuan orang tua tentang pengertian imunisasi di Madrasah Ibtidaiyah Al-Kautsar Palembang tahun 2019

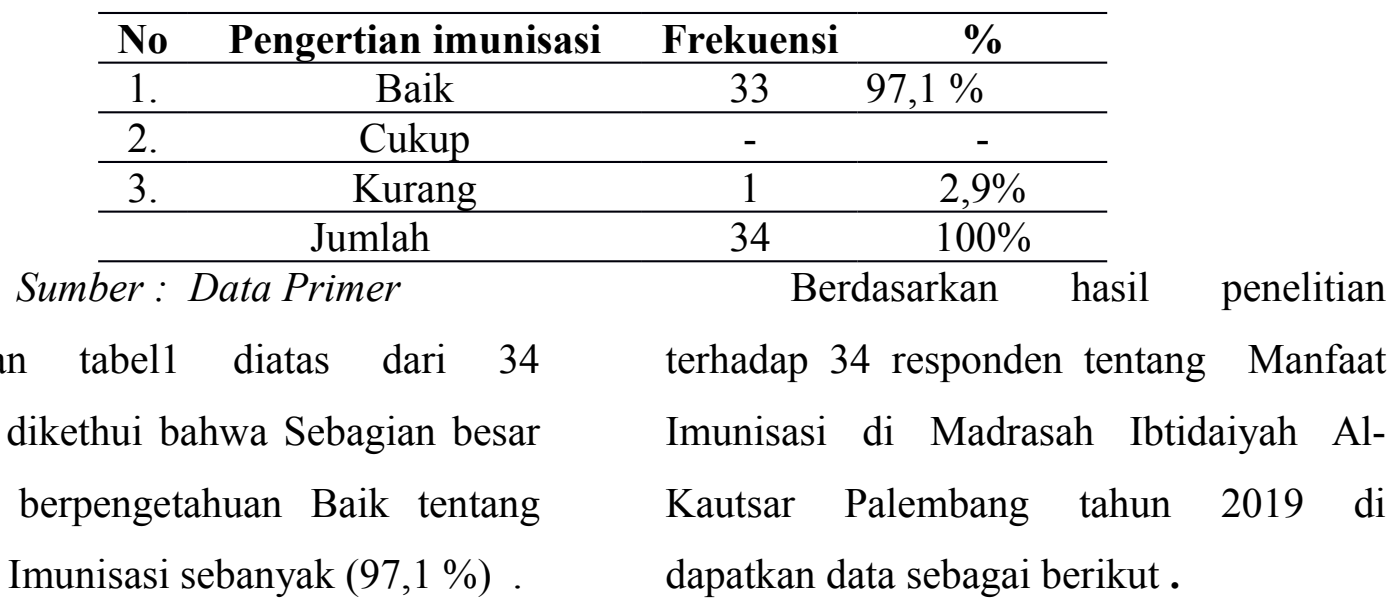

\section{Tabel 2}

Distribusi Frekuensi Responden yang mengetahui manfaat imunisasi di Madrasah Ibtidaiyah Al-Kautsar Palembang Tahun 2019

\begin{tabular}{llll}
\hline No & $\begin{array}{c}\text { Manfaat } \\
\text { imunisasi }\end{array}$ & Frekuensi & $\%$ \\
\hline
\end{tabular}




\begin{tabular}{cccc}
\hline 1. & Baik & 15 & $44,1 \%$ \\
\hline 2. & Cukup & 0 & 0 \\
\hline 3. & Kurang & 19 & $55,9 \%$ \\
\hline & Jumlah & 34 & $100 \%$ \\
\hline
\end{tabular}

Sumber : Data Primer

Dari tabel 2 diatas dari 34

responden di ketahuai bahwa

Sebagian besar responden

berpengetahuan kurang baik

sebanyak $19(55,9 \%)$

\section{Jadwal Imunisasi}

Berdasarkan hasil penelitian terhadap 34 responden tentang Jadwal Imunisasi di Madrasah Ibtidaiyah AlKautsar Palembang tahun 2019 di dapatkan data sebagai berikut

Tabel 3

Distribusi Frekuensi Responden Yang mengetahui Jadwal IMunisasi Di Madrasah Ibtidaiyah Al-Kautsar Palembang Tahun 2019

\begin{tabular}{cccc}
\hline No & Jadwal imunisasi & Frekuensi & \% \\
\hline 1. & Baik & 0 & 0 \\
\hline 2. & Cukup & 25 & $73,5 \%$ \\
\hline 3. & Kurang & 9 & $26,5 \%$ \\
\hline & Jumlah & 34 & $100 \%$ \\
\hline
\end{tabular}

Sumber : Data Primer

Dari tabel 3 diatas dari 34 responden diketahui bahwa ada Sebagian besar responden berpengetahuan cukup sebanyak $25(73,5 \%)$.
4. Dampak Rubella

Berdasarkan hasil penelitian terhadap 34 responden tentang Dampak Imunisasi di Madrasah Ibtidaiyah AlKautsar Palembang tahun 2019 di dapatkan data sebagai berikut

Tabel 4

Distribusi Frekuensi Responden Yang mengetahui Dampak Rubella Di Madrasah Ibtidaiyah Al-Kautsar Palembang Tahun 2019

\begin{tabular}{cccc}
\hline No & Dampak Rubella & Frekuensi & \% \\
\hline 1. & Baik & 29 & $85,3 \%$ \\
\hline 2. & Cukup & 0 & 0 \\
\hline 3. & Kurang & 5 & $14,7 \%$ \\
\hline & Jumlah & 34 & $100 \%$
\end{tabular}

Sumber : Data Primer

Dari tabel 4 diatas dari 34 responden diketahui ada sebagian besar responden berpengetahuan baik sebanyak 29(85,3\%). 


\section{Pengetahuan Tentang Imunisasi}

Berdasarkan hasil penelitian terhadap 34 responden tentang pengetahuan Imunisasi di Madrasah Ibtidaiyah Al-Kautsar Palembang tahun 2019 di dapatkan data sebagai berikut:

\section{Tabel 5}

Distribusi Frekuensi Pengetahuan Orang Tua Tentang Imunisasi Measles Rubella Di Madrasah Ibtidaiyah Al-Kautsar Palembang Tahun 2019.

\begin{tabular}{cccc}
\hline No & Pengetahuan Rubella & Frekuensi & $\mathbf{\%}$ \\
\hline 1. & Baik & 20 & $58,8 \%$ \\
\hline 2. & Cukup & 11 & $32,4 \%$ \\
\hline 3. & Kurang & 3 & $8,8 \%$ \\
\hline & Jumlah & 34 & $100 \%$ \\
\hline Sumber : Data Primer & dengan & pendapat
\end{tabular}

Dari tabel 5 diatas dari 34 responden diketahui ada. Sebagian besar responden berpengetahuan baik sebanyak $20(58,8 \%)$.

\section{PEMBAHASAN}

\section{Hasil Analisis Univariat}

\section{Pengertian Imunisasi Measles}

\section{Rubella}

Berdasarkan hasil penelitian di dapatkan bahwa dari 34 responden yang di teliti Sebagian besar responden berpengetahuan Baik tentang Pengertian Imunisasi sebanyak $(97,1 \%)$

Berdasarkan hasil penelitian di dapatkan bahwa responden menjawab pengertian imunisasi adalah upaya aktif untuk meningkatkan / menimbulkan kekebalan seseorang terhadap suatu penyakit tertentu. Sebagaimana sejalan bahwasanya Imunisasi adalah tindakan untuk memberikan kekebalan aktif buatan dengan cara memasukkan vaksin (antigen) kedalam tubuh host atau manusia dan tujuan Imunisasi MR

adalah untuk mencapai eliminasi campak dan pengendalian rubella/ CRS pada 2020.

1. Hal ini sejalan dengan penelitian Viantri, 2018, yang mengatakan bahwa pemberian Imunisasi di berikan pada kelompok umur tertentu yang paling beresiko terkena penyakit sesuai dengan kajian epidemiologis pada periode waktu tertentu, yang termasuk dalam Imunisasi Tambahan adalah backlog fighting, crash program,PIN (Pekan Imunisasi Nasional ), Sub-PIN. Catch up campaign Campak Dan Imunisasi dalam penanganan KLB (Outbreak Response Immunization / ORI ). (Viantri, 2018).

2. Berdasarkan hasil penelitian dan teori yang ada maka peneliti berpendapat bahwa pengetahuan orang tua siswa Madrasah 
Iftidaiyah Al-Kausar tentang Pengertian Imunisasi sudah baik hal ini di karenakan adanya penyuluhan yang sudah di lakukan petugas puskesmas dan dari dinas kesehatan serta adanya informasi yang di dapatkan dari media masa.

\section{Manfaat Imunisasi Measles Rubella}

Berdasarkan hasil penelitian di dapatkan bahwa dari 34 responden yang di teliti Sebagian besar responden berpengetahuan kurang baik sebanyak $19(55,9 \%)$ Hasil ini menunjukan bahwa responden yang sudah mengetahui tentang manfaat Imunisasi MR lebih kecil dibandingkan yang tidak mengetahui tentang manfaat Imunisasi MR.

Hal ini sejalan dengan penelitian Marimbi bahwasanya manfaat Imunisasi Untuk anak adalah untuk mencegah penderitaan yang di sebabkan oleh wabah yang sering berjangkit. Untuk keluarga menghilangkan kecemasan dan biaya pengobatan bila anak sakit. Mendorong pembentukan keluarga kecil apabila si orang tua yakin bahwa anaknya akan mengalami masa kanak-kanak yang sama. Untuk negara memperbaiki tingkat kesehatan, menciptakan bangsa yang kuat dan berakal untuk melanjutkan pembangunan negara, memperbaiki citra bangsa (Marimbi,2010)
Hal ini sejalan dengan penelitian Viantri, 2018, bahwasanya Imunisasi adalah cara untuk meningkatkan kekebalan seseorang terhadap suatu penyakit, sehingga bila kelak terpajan penyakit tersebut ia tidak menjadi sakit. Kekebalan yang di peroleh dari imunisasi dapat berupa kekebalan pasif maupun aktif (Viantri ,2018)

Berdasarkan hasil penelitian dan teori yang ada maka peneliti berpendapat bahwa yang sudah mengetahui tentang Manfaat Imunisasi MR masih belum terlalu tinggi, hal ini di sebabkan oleh kurangnya pengetahuan orang tua tentang Manfaat Imunisasi meskipun sudah seringnya di lakukan penyuluhan di Madrasah ibtidaiyah alkautsar yang di lakukan oleh pihak puskesmas, dan tenaga kesehatan lainnya dan banyaknya informasi tentang kegagalan imunisasi MR sehingga orang tua enggan untuk memberikan Imunisasi MR pada Anaknya dan mengabaikan manfaat dari Imunisasi MR tersebut.

\section{Jadwal Imunisasi Measles Rubella}

Berdasarkan hasil penelitian di dapatkan bahwa dari 34 responden yang di teliti Sebagian besar responden berpengetahuan cukup sebanyak 25 (73,5\%).Hasil ini menunjukan bahwa responden yang sudah mengetahui tentang jadwal Imunisasi MR lebih besar 
dibandingkan yang tidak mengetahui tentang jadwal Imunisasi MR.

Hal ini sejalan dengan penelitian KKRI, bahwasanya Pemberian vaksin MR tambahan melalui kampanye MR ini di berikan kepada semua anak di Indonesia tanpa mempertimbangkan status vaksinasi campak atau MR sebelumnya. 1 Agustus dan seterusnya Anak-anak di sekolah akan divaksinasi (usia 6 tahun sampai di bawah 15 tahun). Semua sekolah ( Pemerintah, Swasta, Sekolah Agama, dan lain-lain) akan di vaksinasi.1-30 September anak usia 9 bulan sampai 5 tahun akan di vaksinasi, vaksinasi akan di berikan melalui masyarakat / desa, RW/RT di Posyandu, dan Puskesmas. (KKRI,2017).

Hal ini sejalan dengan penelitian Viantri,2018 Bahwasanya Pemberian Imunisasi Tambahan di berikan pada kelompok umur tertentu yang paling beresiko terkena penyakit sesuai dengan kajian epidemiologis pada periode waktu tertentu, yang termasuk dalam Imunisasi Tambahan adalah backlog fighting, crash program,PIN (Pekan Imunisasi Nasional ), Sub-PIN. Catch up campaign Campak Dan Imunisasi dalam penanganan KLB (Outbreak Response Immunization / ORI ). (Viantri, 2018)

Berdasarkan dari hasil penelitian dan teori yang ada, maka menurut analisis peneliti, bahwa yang mengetahui Jadwal
Imunisasi sebanyak 0 responden $(0 \%)$, dan pengetahuan yang cukup sebanyak 25 responden $(73,5 \%)$,) dan yang belum Mengetahui Jadwal Imunisasi Sebanyak 9 responden $(26,5 \%)$.

Berdasarkan hasil penelitian dan teori yang ada maka peneliti berpendapat bahwa pengetahuan orang tua siswa Madrasah Iftidaiyah Al-Kausar tentang Jadwal Imunisasi sudah Cukup baik hal ini di karenakan adanya penyuluhan yang sudah di lakukan petugas puskesmas dan dari dinas kesehatan serta adanya informasi yang di dapatkan dari media masa.

\section{Dampak Rubella}

Berdasarkan hasil penelitian di dapatkan bahwa dari 34 responden yang di teliti sebagian besar responden berpengetahuan baik sebanyak 29(85,3\%). Hasil ini menunjukan bahwa responden yang sudah mengetahui tentang dampak Imunisasi MR lebih besar dibandingkan yang tidak mengetahui tentang dampak Imunisasi MR.

Hal ini sejalan dengan penelitian KKRI bahwasanya Rubella menyebabkan demam, sakit tenggorokan, ruam, sakit kepala, dan merah, mata gatal. Jika seorang wanita mendapat Rubella saat dia hamil, dia bisa mengalami keguguran atau bayinya dapat lahir dengan cacat lahir yang serius seperti kebutaan, tuli, dan lainlain. Ribuan kasus Campak dan Rubella di 
laporkan setiap tahunnya. Anak dapat terlindungi dari penyakit ini dengan vaksinasi yang aman dan efektif. Mendapatkan vaksin MR jauh lebih aman dari pada terkena Campak atau Rubella dan resiko atau Komplikasi terkait. (KKRI, 2018).

Hal ini sejalan dengan penelitian KKRI, 2017 bahwasanya Rubella adalah penyakit yang akut dan ringan yang sering menginfeksi anak dewasa muda yang rentan. Di Indonesia, merupakan salah satu malsalah kesehatan yang memerlukan upaya pencegahan efektif. Data surveilans selama lima tahun terakhir menunjukkan $70 \%$ kasus rubella terjadi ada kelomok usia $<15$ tahun. Selain itu, berdasarakan studi tentang estimasi beban penyakit CRS di Indonesia pada tahun 2013 diperkirakan terdapat 2767 kasus CRS, 82/100.000 terjadi pada ibu usia 15-19 tahun dan menurun menjadi 47/100.000 pada usia ibu 40-44 tahun. (KKRI, 2017)

Berdasarkan hasil penelitian dan teori yang ada maka peneliti berpendapat bahwa pengetahuan orang tua siswa Madrasah Iftidaiyah Al-Kausar tentang Dampak Rubella sudah baik hal ini di karenakan adanya penyuluhan yang sudah di lakukan petugas puskesmas dan dari dinas kesehatan serta adanya informasi yang di dapatkan dari media masa.

\section{Pengetahuan Imunisasi}

Berdasarkan hasil penelitian di dapatkan bahwa dari 34 responden yang di teliti Sebagian besar responden berpengetahuan baik sebanyak 20 (58,8\%). Hasil ini menunjukan bahwa responden yang sudah mempunyai pengetahuan yang baik tentang Imunisasi MR lebih besar dibandingkan yang mempunyai pengetahuan yang cukup dan mempunyai pengetahuan yang kurang tentang Imunisasi MR.

Sebagaimana sejalan dengan pendapat Notoatmodjo bahwasanya Pengetahuan (knowledge) adalah hasil pengindraan manusia atau hasil tahu seseorang terhadap objek tertentu melalui indera yang dimilikinya. Sebagian besar pengetahuan seseorang diperoleh melalui indera pendengaran (telinga) dan indera pengelihatan (mata)

Kecilnya cakupan Imunisasi dikarenakan kurangnya Pengetahuan orang tua tentang MR dan fenomena yang ada di masyarakat mengenai kecacatan setelah di lakukan Imunisasi MR . Berdasarkan study pendahuluan di Madrasah Iftidaiyah AlKautsar bahwa dari 5 orang tua yang di temui saat study pendahuluan ada 4 orang tua yang belum mengetahui tentang imunisasi Measles Rubella dan 1 orang tua masih ragu akan kehalalan vaksin yang akan di berikan, walaupun sebelum melakukan Imunisasi Pihak Sekolah 
memberikan lembar persetujuan pada orang tua agar anaknya di Imunisasi.

Berdasarkan hasil penelitian dan teori yang ada maka peneliti berpendapat bahwa pengetahuan orang tua siswa Madrasah Iftidaiyah Al-Kausar tentang Imunisasi sudah baik hal ini di karenakan adanya penyuluhan yang sudah di lakukan petugas puskesmas dan dari dinas kesehatan serta adanya informasi yang di dapatkan dari media masa. Walaupun demikian tingkat angka capaian Imunisasi di Madrasah Iftidaiyah Al-Kautsar rendah hanya mencapai 19 jiwa $(0,15 \%)$ dari 120 jiwa hal ini di karenakan orang tua beranggapan bahwa Imunisasi MR haram dan di Larang Agama, sehingga perlu adanya kerjasama antara petugas kesehatan dan para Ulama / Tokoh Agama untuk memberikan pengarahan dan kesadaran pada orangtua siswa supaya anaknya boleh di Imunisasi.

\section{KESIMPULAN DAN SARAN}

\section{A. Kesimpulan}

Berdasarkan penelitian yang dilakukan pada bulan Januari Tahun 2019 di Madrasah Ibtidaiyah Al-Kautsar Palembang dengan judul Gambaran Pengetahuan Orang Tua Tentang Imunisasi Measles Rubella Di Madrasah Ibtidaiyah Al-Kautsar Palembang tahun 2019 didapatkan kesimpulan sebagai berikut :
1. Distribusi frekuensi pengetahuan orang tua mengenai pengertian imunisasi MR Bik ( 97,1\%), kurang (2,9\%) di Madrasah Ibtidaiyah Al-Kautsar Palembang Tahun 2019.

2. Distribusi, frekuensi pengetahuan orang tua mengenai manfaat Imunisasi MR Baik (44,1\%), Kurang (55,9\%),di Madrasah Ibtidaiyah Al-Kautsar Palembang tahun 2019

3. Distribusi Frekuensi pengetahuan orang tua mengenai Jadwal Imunisasi MR Cukup (73,5\%),kurang (26,5\%) di Madrasah Ibtidaiyah Al-Kautsar Palembang tahun 2019

4. Distribusi Frekuensi pengetahuan Orang tua mengenai dampak Rubella $\operatorname{Baik}(85,3 \%), \quad$ Kurang(14,7\%) di Madrasah Ibtidaiyah Al-Kautsar Palembang tahun 2019.

5. Distribusi Frekuensi pengetahuan Orang tua mengenai Imunisasi MR Baik(58,8\%), Cukup (32,4\%), Kurang $(8,8 \%)$ di Madrasah Ibtidaiyah AlKautsar Palembang tahun 2019.

\section{B. Saran}

Melihat hasil penelitian diatas, ada beberapa saran yang perlu diperhatikan dan ditindaklanjuti, sebagai berikut

1.

\section{Bagi}

\section{Madrasah Ibtidaiyah Al-Kautsar}

Hasil penelitian ini diharapkan bisa menjadi masukan dalam mengupayakan pengembangan dan peningkatan 
penyuluhan tentang pentingnya Imunisasi

MR pada anak sehingga dapat mencegah dan menurunkan angka kejadian penyakit Measles dan Rubella pada keluarga yang lainnya.

2.

Bagi

\section{STIKES Aisyiyah Palembang}

Hasil penelitin ini dapat dijadikan sebagai bahan referensi dan menambah kepustakaan di STIKES 'AISYIYAH Palembang dalam melakukan penelitian

DAFTAR PUSTAKA

Dinkes, 2018, Imunisasi masal campak dan rubella, WWW.Dinkes.go.id. Jakarta: KKRI. 2 Oktober 2018 pukul 19:00

. 2017, Imunisasi masal campak dan rubella

WWW.Kemenkes.go.id. Jakarta :KKRI. 2 Oktober 2018 pukul 19:00

$\begin{array}{lr}\text { 2018, Capaian } & \text { Imunisasi } \\ \text { Lengkap }(C I L) & \text { Bersama } \\ \text { Melindungi Dan } & \text { Terlindungi. } \\ \text { Palembang: KKRI } & \end{array}$

. 2017, Imunisasi masal campak dan rubella , WWW.Kemenkes.go.id. Jakarta :KKRI. 2 Oktober 2018 pukul 19:00

$2018, \quad$ capaian imunisasi
lengkap(IRL) bersama melindungi
dan terlindungi. Palembang: KKRI

Kurdaningsih Viantri Sept. 2018, Bahan Ajar Keperawatan Anak, Palembang: Stikes Aisyiyah khususnya yang berhubungan dengan Imunisasi Campak dan Rubella.

3.

Bagi

\section{Peneliti yang Akan Datang}

Bagi penelitian yang akan datang diharapkan dapat menggunakan variabel yang lebih bervariasi dan mencakup penelitian yang lebih luas, sehingga penelitian tentang Imunisasi Measles dan Rubella dapat terus berkembang.

Marimbi Hanum. 2010. Tumbuh Kembang, Status Gizi, dan Imunisasi Dasar pada Balita,Hal:110 Yogyakarta: Nuha Medika.

. 2010. Tumbuh Kembang, Status Gizi, dan Imunisasi Dasar pada Balita,Hal:112. Yogyakarta: Nuha Medika.

.2010. Tumbuh Kembang, Status Gizi, dan Imunisasi Dasar pada Balita,Hal:122 Yogyakarta: Nuha Medika

.2010. Tumbuh Kembang, Status Gizi, dan Imunisasi Dasar pada Balita,Hal:123 Yogyakarta: Nuha Medika.

.2010. Tumbuh Kembang, Status Gizi, dan Imunisasi Dasar pada Balita,Hal:127 Yogyakarta: Nuha Medika.

.2010. Tumbuh Kembang, Status Gizi, dan Imunisasi Dasar pada Balita,Hal:131 Yogyakarta: Nuha Medika.

.2010. Tumbuh Kembang, Status Gizi, dan Imunisasi Dasar pada Balita,Hal:135 Yogyakarta: Nuha Medika. 
.2010. Tumbuh Kembang, Status Gizi, dan Imunisasi Dasar pada Balita,Hal:130 Yogyakarta: Nuha Medika.

. 2010. Tumbuh Kembang, Status Gizi, dan Imunisasi Dasar pada Balita,Hal:127. Yogyakarta: Nuha Medika.

. 2010. Tumbuh Kembang, Status Gizi, dan Imunisasi Dasar pada Balita,Hal:128 Yogyakarta: Nuha Medika.

Notoatmodjo, 2011, Kesehatan
Masyarakat Ilmu dan Seni.
Jakarta : Rineka Cipta .2012. Metodelogi Penelitian Kesehata. Jakarta : Rineka Cipta
Novelino Andry. 2018, Ilustrasi Siswa Mengikuti Penyuntikan Vaksin Measles Rubella Dan Campak.Jakarta : CNN Indonesia

Oldi aria saputra, 2018, Ilustrasi

Pemberian Vaksin MR, Palembang: Oldi aria saputra

Riyadi Slamet LA. 2016, Ilmu Kesehatan Masyarakat, hal 88, Yogyakarta : Andi Offset . 2013, Asuhan Keperawatan Pada Anak. Yogyakarta : Graha Ilmu

2016, Ilmu $\begin{gathered}\text { Kesehatan } \\ \text { Masyarakat, hal:90, Yogyakarta } \\ \text {..Andi Offset }\end{gathered}$
2016, Ilmu Kesehatan
$\begin{aligned} & \text { Masyarakat, hal:91, Yogyakarta : } \\ & \text { Andi }\end{aligned}$


